\title{
Characterization of Fludioxonil-Resistant and Pyrimethanil-Resistant Phenotypes of Penicillium expansum from Apple
}

\author{
H. X. Li and C. L. Xiao \\ Department of Plant Pathology, Washington State University, Tree Fruit Research and Extension Center, 1100 North Western Avenue, \\ Wenatchee, WA 98801. \\ Accepted for publication 19 November 2007.
}

\section{ABSTRACT}

Li, H. X., and Xiao, C. L. 2008. Characterization of fludioxonil-resistant and pyrimethanil-resistant phenotypes of Penicillium expansum from apple. Phytopathology 98:427-435.

Penicillium expansum is the primary cause of blue mold, a major postharvest disease of apple. Fludioxonil and pyrimethanil are two newly registered postharvest fungicides for pome fruit in the United States. To evaluate the potential risk of resistance development in $P$. expansum to the new postharvest fungicides, one isolate of each of thiabendazole-resistant (TBZ-R) and -sensitive (TBZ-S) P. expansum was exposed to UV radiation to generate fungicide-resistant mutants. Four fludioxonil highly-resistant mutants $\left(\mathrm{EC}_{50}>1,000 \mu \mathrm{g} / \mathrm{ml}\right)$ and four pyrimethanil-resistant mutants $\left(\mathrm{EC}_{50}>10 \mu \mathrm{g} / \mathrm{ml}\right)$ were tested for sensitivities to thiabendazole, fludioxonil, and pyrimethanil, and fitness parameters including mycelial growth, sporulation on potato dextrose agar (PDA), sensitivity to osmotic stress, and pathogenicity and sporulation on apple fruit. The stability of resistance of the mutants was tested on PDA and apple fruit. Efficacy of the three fungicides to control blue mold incited by the mutants was evaluated on apple fruit. Six fungicide-resistant phenotypes were identified among the parental wild-type isolates and their mutants based upon their resistance levels. All four fludioxonil highly-resistant mutants were sensitive to pyrimethanil and retained the same phenotypes of resistance to TBZ as the parental isolates. All four pyrimethanil-resistant mutants had a low level of resistance to fludioxonil with a resistance factor $>15$. The two pyrimethanil-resistant mutants derived from a TBZ-S isolate be- came resistant to TBZ at $5 \mu \mathrm{g} / \mathrm{ml}$. After 20 successive generations on PDA and four generations on apple fruit, the mutants retained the same phenotypes as the original generations. All mutants were pathogenic on apple fruit at both 0 and $20^{\circ} \mathrm{C}$, but fludioxonil highly-resistant mutants were less virulent and produced fewer conidia on apple fruit than pyrimethanil-resistant mutants and their parental wild-type isolates. Compared with the parental isolates, all four fludioxonil highly-resistant mutants had an increased sensitivity to osmotic stress on PDA amended with $\mathrm{NaCl}$, while the pyrimethanil-resistant mutants did not. Pyrimethanil was effective against blue mold caused by fludioxonil-resistant mutants at both 0 and $20^{\circ} \mathrm{C}$. Pyrimethanil and fludioxonil reduced blue mold incited by pyrimethanil-resistant mutants during 12 -week storage at $0^{\circ} \mathrm{C}$ but were not effective at $20^{\circ} \mathrm{C}$. TBZ was not effective against pyrimethanil-resistant mutants derived from TBZ-S wild-type isolates at room temperature but provided some control at $0^{\circ} \mathrm{C}$. The results indicate that: (i) a fitness cost was associated with fludioxonil highly resistant mutants of $P$. expansum in both saprophytic and pathogenic phases of the pathogen but not pyrimethanil-resistant mutants; (ii) pyrimethanil possessed a higher risk than fludioxonil in the development of resistance in P. expansum; and (iii) triple resistance to the three apple-postharvest fungicides could emerge and become a practical problem if resistance to pyrimethanil develops in $P$. expansum populations.

Additional keywords: anilinopyrimidine, fungicide resistance, multi-drug resistance, phenylpyrrole.
Penicillium expansum (Link) Thom. is the primary cause of blue mold, a major postharvest fruit rot disease in apple (35). Conidia are the main type of inoculum responsible for fruit infection by $P$. expansum. Conidia of $P$. expansum are present in the orchards, fruit storage rooms, dump-tank and flotation-tank water, and packing facilities $(35,37,38,40)$. $P$. expansum is essentially a wound-invading pathogen. Wounds such as punctures, and bruises on the fruit created at harvest and during postharvest handling are the primary avenue for infection of fruit by the fungus (35).

Chemical control remains the main measure for the control of postharvest diseases in pome fruits $(1,8)$. Benzimidazole fungicides, including benomyl, thiabendazole (TBZ), and thiophanatemethyl, were introduced in the late 1960s for postharvest use on pome fruits (1). Resistance of $P$. expansum to benzimidazole fungicides was first observed in the mid-1970s on pear in the mid-Columbia region of Oregon and Washington (4), and on apple in New York (36). Benomyl and thiophanate-methyl are currently no longer registered for postharvest use in the United

Corresponding author: C. L. Xiao; E-mail address: clxiao@wsu.edu

doi:10.1094/PHYTO-98-4-0427

(C) 2008The American Phytopathological Society
States. TBZ is commonly used as either a drench treatment prior to storage or an online treatment at packing for control of postharvest diseases of apple, but resistance to TBZ in $P$. expansum often results in the failure of blue mold control $(10,22)$.

In 2004, two new fungicides, fludioxonil and pyrimethanil, were registered for postharvest use on pome fruits in the United State. Fludioxonil and pyrimethanil belong to phenylpyrrole and anilinopyrimidine classes, respectively. Both fungicides are highly effective in inhibiting conidial germination and germ-tube elongation of $P$. expansum $(9,26)$. The baseline sensitivity to fludioxonil and pyrimethanil in $P$. expansum populations from apple in Washington State has been established (26). The P. expansum populations from apple in Washington State prior to the commercial use of these two fungicides consisted of a mixture of phenotypes varying in sensitivity to fludioxonil and pyrimethanil (26), but both thiabendazole-sensitive (TBZ-S) and -resistant (TBZ-R) isolates of $P$. expansum were sensitive to fludioxonil and pyrimethanil, and can be effectively controlled by the two new fungicides $(11,26,39)$. Fludioxonil and pyrimethanil can thus be used as alternatives to TBZ for control of blue mold and other postharvest diseases of pome fruits, and particularly as a tool for control of blue mold caused by TBZ-R strains of $P$. expansum $(10,26)$.

Inherent characteristics of both pathogen and fungicide contribute to the development of resistant populations of a fungal 
pathogen to a fungicide (5). Fludioxonil and pyrimethanil are considered medium-risk resistance fungicides, but $P$. expansum is a pathogen, like $B$. cinerea, because of their short life cycles and abundant reproduction, have the propensity to acquire fungicide resistance rapidly and are high-risk pathogens for the development of fungicide resistance (5). Field resistance to fludioxonil in Alternaria spp. from crucifers (17) and in $P$. digitatum from lemon has been reported $(18,19)$. There are numerous reports on the occurrence of field isolates of $B$. cinerea resistant to anilinopyrimidines several years after its registration for commercial use (6,13,14,21,23,31-33), and multiple resistance of $B$. cinerea to anilinopyrimidines, dicarboximides, and fenhexamid has also been reported (23), indicating a high risk for build-up of resistance to this class of fungicides in fungal pathogens.

Before the fungicide-resistant population of a fungal pathogen becomes detectable in the field, laboratory fungicide-resistant mutants could be used in early studies to assess the risk in the development of resistance to the fungicide. Fitness of fungicideresistant isolates and the potential cross resistance among the commonly used fungicides are very important parameters that could provide an indication for the risk of build-up of field fungicide resistance in the population of a target pathogen (5). Experience with TBZ resistance in $P$. expansum and the occurrence of resistance/multiple resistance to pyrimethanil and fludioxonil in other fungal pathogens suggest that it is prudent to assess the potential patterns of cross resistance/multiple resistance to the three apple-postharvest fungicides in P. expansum. Currently no information is available about the risk of the development of resistance to fludioxonil and pyrimethanil in $P$. expansum populations from pome fruits. In the present study, we used a mutagenesis approach to generate fungicide-resistant mutants of $P$. expansum in the laboratory, and then used the mutants to assess parameters associated with the risk of development of fungicide resistance. A proactive approach to understand the potential risk in the development of resistance to these two new postharvest fungicides in $P$. expansum would help us develop relevant strategies to avoid or delay the build-up of such resistance and thus prolong the effectiveness of fludioxonil and pyrimethanil for controlling blue mold in apple.

The specific objectives of this study were to (i) generate fludioxonil- and pyrimethanil-resistant mutants of $P$. expansum in the laboratory; (ii) assess potential cross resistance or multiple resistance of the fungicide-resistant mutants to the three applepostharvest fungicides; (iii) estimate saprophytic and pathogenic fitness parameters of the fungicide-resistant mutants; (iv) assess resistance stability of fungicide-resistant mutants; and (v) test the efficacy of the three apple-postharvest fungicides for controlling blue mold incited by the fludioxonil-resistant and pyrimethanilresistant mutants.

\section{MATERIALS AND METHODS}

Fungicides and fruit. Technical grade fludioxonil (a.i., 93\%; Syngenta Inc., Switzerland) and pyrimethanil (a.i., 96\%; Janssen Pharmaceutica N.V., Belgium) were dissolved in acetone and adjusted to make 50 and $30 \mathrm{mg} / \mathrm{ml}$ stock solutions, respectively. Thiabendazole (a.i., 99\%; Sigma-Aldrich Co., St. Louis, MO) was dissolved in methanol and adjusted to $0.5 \mathrm{mg} / \mathrm{ml}$ in a stock solution. The formulated thiabendazole (Mertect 340F; Syngenta Crop Protection, Greensboro, NC), fludioxonil (Scholar 50WP; Syngenta Crop Protection), and pyrimethanil (Penbotec 400SC; Janssen Pharmaceutica N.V) were suspended in deionized water following the labels.

We used organic 'Red Delicious' apple fruit throughout the study to avoid potential interference by preharvest fungicide residues on the fruit. Fruit were either harvested from a commercial orchard or purchased from a local fruit packinghouse. No known disease-resistance-inducing products were applied to the fruit.
Fruit were stored at $0^{\circ} \mathrm{C}$ either in air or in controlled atmosphere (CA) until use.

Mutagenesis. Two wild-type isolates of $P$. expansum, CLX 3354 (TBZ-S) and CLX 3294 (TBZ-R) isolated from decayed apples sampled from commercial fruit packinghouses, were used as parental isolates to generate fungicide-resistant mutants. Conidial suspensions were prepared by transferring dry conidia from a 7-day-old potato dextrose agar (PDA; Difco Laboratories, Detroit, MI) culture with a sterile 4-mm-diameter plastic loop to a 20-ml screw-cap tube containing $10 \mathrm{ml}$ of sterile deionized water with $0.01 \%$ Tween 20 , and the concentrations of conidia of resulting suspensions were estimated with a hemacytometer (37). An aliquot of $0.2 \mathrm{ml}$ of conidial suspension each of isolate W1 with $3.2 \times 10^{7}$ conidia per $\mathrm{ml}$ and isolate $\mathrm{W} 2$ with $3.7 \times 10^{7}$ conidia per $\mathrm{ml}$ was spread with a stainless steel rod onto PDA amended with $10 \mu \mathrm{g} / \mathrm{ml}$ fludioxonil or onto an L-asparagine-based agar (15) $(1 \mathrm{~g}$ of $\mathrm{K}_{2} \mathrm{HPO}_{4}, 1 \mathrm{~g}$ of $\mathrm{MgSO}_{4} \cdot 7 \mathrm{H}_{2} \mathrm{O}, 0.5 \mathrm{~g}$ of $\mathrm{KCl}, 0.01 \mathrm{~g}$ of $\mathrm{FeSO}_{4} \cdot 7 \mathrm{H}_{2} \mathrm{O}, 2 \mathrm{~g}$ of L-asparagine, $22 \mathrm{~g}$ of glucose, and $15 \mathrm{~g}$ of agar) amended with pyrimethanil at $10 \mu \mathrm{g} / \mathrm{ml}$. There were five replicate plates for each isolate. Plates were incubated at $20^{\circ} \mathrm{C}$ for $5 \mathrm{~h}$ in the dark and then exposed to ultraviolet light (plates were placed $27 \mathrm{~cm}$ from the light at $253.7 \mathrm{~nm}$ ) for $30 \mathrm{~s}$. This mutagenic treatment resulted in at least $99 \%$ lethality. Plates were then sealed with Parafilm, packed in plastic bags and incubated at $20^{\circ} \mathrm{C}$ in the dark for 7 days. The emergent colonies were transferred twice to the fungicide-amended media of the same composition as used in the selection procedure, and thereafter cycled twice on fungicide-free PDA before testing for fungicide sensitivity (42). A mycelial growth assay for fludioxonil and a germtube elongation assay for pyrimethanil (26) were used to determine whether mutants remained resistant to these two fungicides. Resistance to fludioxonil was screened by examining the colony growth on PDA amended with fludioxonil at 0 and $0.5 \mu \mathrm{g} / \mathrm{ml}$, after incubation for 5 days at $20^{\circ} \mathrm{C}$. The mutants that were able to grow on PDA amended with fludioxonil were considered fludioxonil-resistant (FR). For pyrimethanil, at least three parallel lines were marked on the reverse of an agar plate $(10 \mathrm{~g}$ of glucose, $2 \mathrm{~g}$ of $\mathrm{K}_{2} \mathrm{HPO}_{4}, 2 \mathrm{~g}$ of $\mathrm{KH}_{2} \mathrm{PO}_{4}$, and $12.5 \mathrm{~g}$ of agar) (25) amended with pyrimethanil at 0 and $1 \mu \mathrm{g} / \mathrm{ml}$. A loop of the conidial suspension (approximately $10^{5} \mathrm{conidia} / \mathrm{ml}$ ) was streaked along each line. After incubation for approximately $44 \mathrm{~h}$, plates were examined under a microscope for germ-tube elongation. Mutants with similar length of germ tubes on plates amended with pyrimethanil at $1 \mu \mathrm{g} / \mathrm{ml}$ with those on plates without the fungicide were considered pyrimethanil-resistant (PR). After subculturing for 10 successive generations on PDA without fungicides, fludioxonil- and pyrimethanil-resistant mutants were tested again for resistance to fludioxonil and pyrimethanil, respectively. Two fludioxonil-resistant and two pyrimethanil-resistant mutants derived from each of the isolates W1 (TBZ-S) and W2 (TBZ-R) with stable resistance to fludioxonil and pyrimethanil were selected for further study.

Phenotypes of fungicide-resistant mutants. The in vitro fungicide sensitivities of the two wild-type parental isolates (W1 and W2) and the eight representative fungicide-resistant mutants (FR1 to FR4 for fludioxonil and PR1 to PR4 for pyrimethanil) were determined by a mycelial growth assay for fludioxonil or a germtube elongation assay for pyrimethanil (26). Sensitivity to fludioxonil $(0,3.125,6.25,12.5,25$, and $50 \mu \mathrm{g} / \mathrm{ml})$ of the fludioxonilresistant mutants, sensitivity to fludioxonil $(0,0.015,0.05,0.15$, $0.5,1,1.5$, and $5 \mu \mathrm{g} / \mathrm{ml}$ ) of the pyrimethanil-resistant mutants, and sensitivity to thiabendazole $(0,0.2,0.4,0.6,1,2.5,5$, and $10 \mu \mathrm{g} / \mathrm{ml}$ ) of W1 isolate and the fungicide-resistant mutants derived from W1 were assessed with mycelial growth assays. In order to obtain the $\mathrm{EC}_{50}$ values of thiabendazole for the fungicideresistant mutants derived from $\mathrm{W} 2$ (TBZ-R) and $\mathrm{EC}_{50}$ values of fludioxonil for the fludioxonil-resistant mutants, a formulated thiabendazole (Mertect 340F) $(0,100,250,500,750$, and 1,000 $\mu \mathrm{g} / \mathrm{ml}$ ) 
and a formulated fludioxonil (Scholar 50WP) (0, 100, 250, 500, 750 , and $1,000 \mu \mathrm{g} / \mathrm{ml}$ ) were used. To make fresh mycelial inoculum, $1 \mathrm{ml}$ of conidial suspension (approximately $10^{6}$ conidia $/ \mathrm{ml}$ ) was mixed into $16 \mathrm{ml}$ of molten PDA at $50^{\circ} \mathrm{C}$, and the medium was then poured immediately into a petri plate. Cultures were incubated at $20^{\circ} \mathrm{C}$ for $24 \mathrm{~h}$. Agar plugs were cut from the cultures with a 6-mm-diameter cork borer. One such plug was placed upside-down on fungicide-amended PDA in each plate. Three replicate plates were used for each concentration for each isolate. Colony diameters were measured after 7 days at $20^{\circ} \mathrm{C}$, and $\mathrm{EC}_{50}$ values for all isolates were estimated.

To determine $\mathrm{EC}_{50}$ values of pyrimethanil, conidial suspensions with approximately $10^{5}$ conidia/ml of the four fludioxonil-resistant mutants (F1 to F4) and the parental isolates were streaked onto the previously described L-asparagine-based agar plates amended with pyrimethanil at $0,0.15,0.25,0.35$, and $0.5 \mu \mathrm{g} / \mathrm{ml}$. Six concentrations of pyrimethanil at $0,5,10,15,20$, and $30 \mu \mathrm{g} / \mathrm{ml}$ were used to determine the $\mathrm{EC}_{50}$ values of pyrimethanil for the four pyrimethanil-resistant mutants. Cultures were incubated at $20^{\circ} \mathrm{C}$ for approximately $42 \mathrm{~h}$. The lengths of germ tubes (50 germinated conidia for each treatment) were estimated under a microscope using a micrometer. The experiment was performed three times.

Resistance factor ( $\mathrm{RF}$, a ratio of $\mathrm{EC}_{50}$ for a fungicide-resistant mutant relative to the $\mathrm{EC}_{50}$ for the parental isolate) (7) and minimum inhibitory concentration (MIC) (31) are commonly used to describe phenotypes of fungicide-resistant isolates or mutants. For resistance to TBZ, an MIC of $5 \mu \mathrm{g} / \mathrm{ml}$ is commonly used (37). In our study, we determined if $\mathrm{EC}_{50}$ values of $\mathrm{TBZ}$ for mutants derived from TBZ-S were shifted compared to the wild-type parental isolate. To determine whether these mutants derived from TBZ-S became resistant to TBZ or more sensitive to TBZ, mycelial growth of these mutants was also tested on PDA amended with TBZ at 2.5 and $5 \mu \mathrm{g} / \mathrm{ml}$. In this study, for TBZ, an isolate was classified as sensitive (S) if the $\mathrm{EC}_{50}$ value was $<1 \mu \mathrm{g} / \mathrm{ml}$ and MIC for mycelial growth $\leq 5 \mu \mathrm{g} / \mathrm{ml}$; low level of resistance (LR), with the $\mathrm{EC}_{50}$ value between 1 and $10 \mu \mathrm{g} / \mathrm{ml}$; and highly resistant (HR), with the $\mathrm{EC}_{50}$ value $>100 \mu \mathrm{g} / \mathrm{ml}$. For fludioxonil, an isolate was classified as sensitive $(\mathrm{S})$ with the $\mathrm{EC}_{50}$ value $<0.1 \mu \mathrm{g} / \mathrm{ml}$ for mycelial growth; LR with the $\mathrm{EC}_{50}$ value between 0.1 and $1 \mu \mathrm{g} / \mathrm{ml}$; HR with the $\mathrm{EC}_{50}$ value $>50 \mu \mathrm{g} / \mathrm{ml}$ (12).

Saprophytic fitness of fungicide-resistant mutants. The eight fungicide-resistant mutants were tested for mycelial growth, conidial germination, germ-tube elongation, sporulation, sensitivity to osmotic pressure, and stability of resistant phenotypes compared with the parental isolates. One 6-mm-diameter mycelial plug from a 24-h-old culture of each isolate was placed at the center of each of the three PDA plates, and colony diameter in each plate was measured after 7 days at $20^{\circ} \mathrm{C}$ and 10 weeks at $0^{\circ} \mathrm{C}$ in the dark. The reverses of PDA plates were marked with four to five parallel lines. A loop of the conidial suspension (approximately $10^{5}$ conidia/ml) made from 7-day-old cultures were streaked along each line. After incubation at $20^{\circ} \mathrm{C}$ in the dark for $24 \mathrm{~h}$, the percentage of conidial germination (about 300 conidia for each isolate) was determined and the lengths of germ tubes (150 germinated conidia for each isolate) were measured with a micrometer. Only conidia with a germ tube at least twice its length were considered germinated.

To determine conidial production in the absence of the fungicides, an aliquot of $1 \mathrm{ml}$ of each conidial suspension (approximately $1 \times 10^{4}$ conidia/ml) was added to a 125 -ml flask containing $20 \mathrm{ml}$ of PDA at $50^{\circ} \mathrm{C}$, shaken at $150 \mathrm{rpm}$ for $30 \mathrm{~s}$ and poured into a petri plate (95-mm-diameter). Three plates for each isolate were incubated in the dark at $20^{\circ} \mathrm{C}$ for 7 days and $0^{\circ} \mathrm{C}$ for 10 weeks. Five agar plugs were cut from the colony in a "+" pattern in each plate with a 6-mm-diameter cork borer, gently crushed with a pestle in a mortar, and then poured into a flask containing either 100 or $200 \mathrm{ml}$ of sterile deionized water with
$0.01 \%$ Tween 20. The suspension was stirred for $5 \mathrm{~min}$, and the concentration of the conidial suspension was estimated with a hemacytometer. The number of conidia produced on five agar plugs from each plate was calculated.

To test osmotic sensitivity, three 6-mm-diameter mycelial plugs from 24-h-old PDA cultures of each fungicide-resistant mutant and their parental isolates of $P$. expansum were transferred to PDA amended with $0,1,2,4,6$, or $8 \%$ (wt/vol) $\mathrm{NaCl}$, respectively (30). The colony diameters were measured after 7 days at $20^{\circ} \mathrm{C}$. The percentage of the mycelial radial growth inhibition was calculated. This experiment was performed twice.

Pathogenic fitness of fungicide-resistant mutants. Red Delicious fruit that had been stored in air at $0^{\circ} \mathrm{C}$ for 1 to 2 months were used in this study. Prior to experiment, fruit were surfacedisinfested for $5 \mathrm{~min}$ in $0.6 \%$ sodium hypochlorite solution, rinsed three times with deionized water, and air dried. Each fruit was wounded with a 4-mm-diameter finish-nail head into $3 \mathrm{~mm}$ in depth and subsequently inoculated by placing $20 \mu \mathrm{l}$ of the conidial suspension (approximately $1 \times 10^{4}$ conidia $/ \mathrm{ml}$ ) with a pipette into the wound. Fruit treated with sterile water were used as a noninoculated control. Nine replicate fruit per isolate were inoculated and then placed on muffin trays in a plastic box covered with its lid. A 50-ml volume of water was added to the bottom of the box to maintain high relative humidity. The plastic boxes were kept at $20^{\circ} \mathrm{C}$ for 10 days. In addition, 20 replicate apples per isolate were inoculated and placed on fiberboard fruit trays and stored in cardboard boxes at $0^{\circ} \mathrm{C}$ for 12 weeks. Fruit were considered decayed when a lesion developed around the wound and lesion diameter was measured. Percent fruit with decay symptoms and virulence index (the ratio of the lesion size of the fungicide-resistant mutant relative to the lesion size of its parental wild-type isolate) were calculated. Three decayed fruit from each treatment were selected for re-isolation of the causal agent.

Sporulation of fungicide-resistant mutants on apple fruit was evaluated. Fruit that had been stored at $0^{\circ} \mathrm{C}$ in $\mathrm{CA}$ for 5 months were used in this study. Fruit were surface-disinfested for $5 \mathrm{~min}$ in $0.6 \%$ sodium hypochlorite solution, rinsed three times with deionized water, and air dried. Five apples were sliced longitudinally with a sterile knife to create a similar size area (approximately $70 \times 60 \mathrm{~mm}$ ) on each fruit. The center of the flat surface of the sliced apple was wounded with a finish-nail head (4-mmdiameter and 3-mm depth). Each wound was inoculated with $20 \mu \mathrm{l}$ of conidial suspension (approximately $1 \times 10^{4}$ conidia/ml) of each isolate and incubated at $20^{\circ} \mathrm{C}$ for 7 days and $0^{\circ} \mathrm{C}$ for 10 weeks. Lesion diameter of each fruit was measured and the decayed area was removed with a sterile scalpel and put into a beaker containing either 100 or $200 \mathrm{ml}$ of sterile deionized water with $0.01 \%$ Tween 20 . The suspension in each beaker was stirred for $5 \mathrm{~min}$. The concentration of the conidial suspension was estimated with a hemacytometer. The number of conidia produced on each apple was calculated.

Stability of resistance of fungicide-resistant mutants. Stability of fungicide-resistant isolates in vitro was assessed by successive transfers of the fungicide-resistant mutants on fungicidefree PDA for 20 generations. At the end of the 20th generation, the $\mathrm{EC}_{50}$ values of fludioxonil for the fludioxonil-resistant mutants and $\mathrm{EC}_{50}$ values of pyrimethanil, thiabendazole, and fludioxonil for the pyrimethanil-resistant mutants were determined with the assays as previously described. This experiment was performed two times.

Resistance stability of fungicide-resistant mutants on apple fruit was evaluated. Fruit that had been stored at $0^{\circ} \mathrm{C}$ in $\mathrm{CA}$ for 5 months were used in this study. Fruit were surface-sterilized, wounded, and inoculated as previously described with the conidial suspensions (approximately $1 \times 10^{4}$ conidia $/ \mathrm{ml}$ ) of the eight fungicide-resistant mutants and two parental isolates, and incubated at $20^{\circ} \mathrm{C}$. Nine replicate apples per isolate were inoculated 
and placed on muffin trays in plastic boxes, and $50 \mathrm{ml}$ of water was added to the box to maintain high relative humidity. Lesion diameter was measured 10 days after inoculation. One decayed apple from each inoculum of each generation was selected for reisolation. The inoculum of the isolate recovered from decayed fruit was used for inoculation of fruit for the following generation. After four successive generations of inoculation using the same method as described above, $\mathrm{EC}_{50}$ values of fludioxonil for the fludioxonil-resistant mutants of the fourth generation on apple fruit and $\mathrm{EC}_{50}$ values of pyrimethanil, thiabendazole, and fludioxonil for the pyrimethanil-resistant mutants, and the virulence index of each generation were determined. This experiment was performed three times.

Efficacy of the fungicides for control of blue mold incited by fludioxonil- and pyrimethanil-resistant mutants of $P$. expansum. Two fludioxonil-resistant (FR2 and FR3) and two pyrimethanil-resistant mutants (PR2 and PR4) and their parental wildtype isolates (W1 and W2) were included in the test. Conidial suspensions (approximately $1 \times 10^{4}$ conidia/ml) made from 7-day-old PDA cultures grown at $20^{\circ} \mathrm{C}$ were used as inoculum for fruit inoculation. Organic Red Delicious fruit that had been stored in $\mathrm{CA}$ at $0^{\circ} \mathrm{C}$ for about 4 months were used for this study. Fruit were surface-sterilized, wounded, and inoculated as described previously At approximately $1 \mathrm{~h}$ after inoculation, fruit were dipped for $1 \mathrm{~min}$ in either deionized water (control) or in one of the three following fungicide solutions: thiabendazole applied as Mertect 340F (1.25 ml/liter), fludioxonil applied as Scholar 50WP (0.6 g/liter), and pyrimethanil applied as Penbotec 400SC (1.25 $\mathrm{ml} /$ liter). Twenty apple fruit per replicate and three replicates were used for each isolate. Fruit were air-dried for $15 \mathrm{~min}$ and then placed on fruit trays and stored in cardboard boxes at room temperature for 10 days (average $23.8^{\circ} \mathrm{C}$, from 21.7 to $24.8^{\circ} \mathrm{C}$ ) and $0^{\circ} \mathrm{C}$ for 12 weeks, after which decay was evaluated. Fruit was considered decayed when a lesion developed at the inoculation site. Lesion diameter was measured and percent fruit with decay symptoms was calculated. For the experiment conducted at $0^{\circ} \mathrm{C}$, after cold storage fruit were also stored at room temperature for an additional week, after which decay was evaluated. In order to confirm the results with the pyrimethanil-resistant mutants, another pyrimethanil-resistant mutant (PR1) also was tested in a separate experiment following the same method and incubated at $20^{\circ} \mathrm{C}$ for 10 days. This experiment was performed twice.

Statistical analysis. All experiments were conducted at least twice and the data were pooled for analysis because results from repeated experiments did not differ statistically $(P>0.05)$. A liner regression of the percent inhibition of mycelial growth relative to the control versus the logarithmic transformation for each concentration of fludioxonil and thiabendazole were obtained using SAS PROC REG (version 9.1, SAS Institute, Cary, NC). $\mathrm{EC}_{50}$ values were then calculated based on the models. The $\mathrm{EC}_{50}$ values of pyrimethanil based on the germ-tube elongation assay were calculated based on liner regression models without the logarithmic transformation of fungicide concentrations. A $t$ test was performed to compare the stability of fungicide resistance at original generation versus at the 20th generation on PDA or the fourth generation on apple fruit using SAS. The differences between the fungicide-resistant mutants and their parental isolates on saprophytic and pathogenic fitness parameters and the differences among treatments in the fungicide efficacy experiment were analyzed by analysis of variance using PROC GLM of SAS and means were separated by the Waller-Duncan K-ratio $t$ test. Sporulation data were transformed to logarithms and all data in percentages were transformed with the arcsine-square-root transformation prior to statistical analysis.

\section{RESULTS}

Induction of fludioxonil- and pyrimethanil-resistant mutants. Fludioxonil- and pyrimethanil-resistant mutants of $P$. expansum were readily obtained by exposing conidia on PDA amended with fludioxonil at $10 \mu \mathrm{g} / \mathrm{ml}$ and an L-asparagine-based agar amended with pyrimethanil at $10 \mu \mathrm{g} / \mathrm{ml}$ to UV irradiation, respectively. The frequency of UV-induced mutagenesis was approximately $10^{-7}$ among the total number of conidia that were exposed. Twenty-four fludioxonil-resistant and 20 pyrimethanilresistant mutants derived from the TBZ-S isolate (W1), and 16 fludioxonil-resistant and eight pyrimethanil-resistant mutants derived from the TBZ-R isolate (W2) were obtained. After the mutants were subcultured on fungicide-amended media twice and thereafter on fungicide-free PDA twice, 29 fludioxonil-resistant and 10 pyrimethanil-resistant mutants remained resistant to the fungicides according to the initial screening (fludioxonil at $0.5 \mu \mathrm{g} / \mathrm{ml}$ and pyrimethanil at $1 \mu \mathrm{g} / \mathrm{ml}$ as discriminatory concentrations). Four representative fludioxonil-resistant mutants and four pyrimethanil-resistant mutants (two derived from each of W1 and W2 for both fungicides) were chosen for further studies.

Phenotypes of fungicide-resistant mutants. Six phenotypes of $P$. expansum were detected among the fungicide-resistant mutants and their wild-type parental isolates based upon their resistance levels (Table 1). All four fludioxonil-resistant mutants (FR1 to FR4) were highly resistant to fludioxonil $\left(\mathrm{EC}_{50}>1,000 \mu \mathrm{g} / \mathrm{ml}\right)$

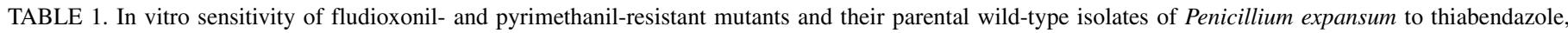
fludioxonil, and pyrimethanil

\begin{tabular}{|c|c|c|c|c|c|}
\hline \multirow[b]{2}{*}{ Culture no. ${ }^{\mathrm{v}}$} & \multirow[b]{2}{*}{ Isolate code $\mathrm{c}^{\mathrm{w}}$} & \multirow[b]{2}{*}{ Phenotype $^{\mathrm{x}}$} & \multicolumn{3}{|c|}{$\mathrm{EC}_{50}(\mu \mathrm{g} / \mathrm{ml})^{\mathrm{y}}$} \\
\hline & & & Thiabendazole & Fludioxonil & Pyrimethanil \\
\hline CLX3354 & W1 & $\mathrm{TBZ}^{\mathrm{S}} \mathrm{Flu}^{\mathrm{S}} \mathrm{Pyr}^{\mathrm{S}}$ & $0.595 \pm 0.019^{z}$ & $0.017 \pm 0.001$ & $0.191 \pm 0.018$ \\
\hline CLX3294 & W2 & $\mathrm{TBZ}^{\mathrm{HR}} \mathrm{Flu}^{\mathrm{SPyr}}{ }^{\mathrm{S}}$ & $>1,000$ & $0.021 \pm 0.001$ & $0.189 \pm 0.018$ \\
\hline CLX4277 & FR1 & $\mathrm{TBZ}^{\mathrm{S}} \mathrm{Flu}^{\mathrm{HR}} \mathrm{Pyr}^{\mathrm{S}}$ & $0.220 \pm 0.005$ & $>1,000$ & $0.195 \pm 0.032$ \\
\hline CLX4284 & FR2 & $\mathrm{TBZ}^{\mathrm{S}} \mathrm{Flu}^{\mathrm{HR}} \mathrm{Pyr}^{\mathrm{S}}$ & $0.461 \pm 0.021$ & $>1,000$ & $0.166 \pm 0.020$ \\
\hline CLX4262 & FR3 & $\mathrm{TBZ}^{\mathrm{HR}} \mathrm{Flu}^{\mathrm{HR}} \mathrm{Pyr}^{\mathrm{S}}$ & $>1,000$ & $>1,000$ & $0.158 \pm 0.026$ \\
\hline CLX4272 & FR4 & $\mathrm{TBZ}^{\mathrm{HR}} \mathrm{Flu}^{\mathrm{HR}} \mathrm{Pyr}^{\mathrm{S}}$ & $>1,000$ & $>1,000$ & $0.160 \pm 0.025$ \\
\hline CLX4256 & PR1 & $\mathrm{TBZ}^{\mathrm{LR}} \mathrm{Flu}^{\mathrm{LR}} \mathrm{Pyr}^{\mathrm{R}}$ & $1.602 \pm 0.017$ & $0.421 \pm 0.016$ & $13.997 \pm 2.135$ \\
\hline CLX4258 & PR2 & $\mathrm{TBZ}^{\mathrm{LR}} \mathrm{Flu}^{\mathrm{LR}} \mathrm{Pyr}^{\mathrm{R}}$ & $1.406 \pm 0.064$ & $0.657 \pm 0.032$ & $15.133 \pm 0.926$ \\
\hline CLX4252 & PR3 & $\mathrm{TBZ}^{\mathrm{HR}} \mathrm{Flu}^{\mathrm{LR}} \mathrm{Pyr}^{\mathrm{R}}$ & $>1,000$ & $0.321 \pm 0.009$ & $13.638 \pm 1.124$ \\
\hline CLX4253 & PR4 & $\mathrm{TBZ}^{\mathrm{HR}} \mathrm{Flu}^{\mathrm{LR}} \mathrm{Pyr}^{\mathrm{R}}$ & $>1,000$ & $0.365 \pm 0.007$ & $13.554 \pm 0.936$ \\
\hline
\end{tabular}

${ }^{v}$ All cultures are maintained at the Tree Fruit Research and Extension Center, Washington State University, Wenatchee, WA.

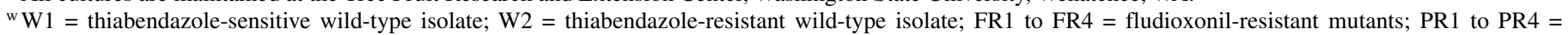
pyrimethanil-resistant mutants. FR1, FR2, PR1, and PR2 were derived from W1; and FR3, FR4, PR3, and PR4 were derived from W2.

$\times \mathrm{TBZ}=$ thiabendazole, Flu $=$ fludioxonil, $\mathrm{Pyr}=$ pyrimethanil, $\mathrm{S}=$ sensitive, $\mathrm{R}=$ resistant, $\mathrm{LR}=$ lowly resistant, HR $=$ highly resistant.

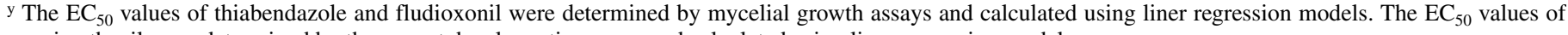
pyrimethanil were determined by the germ-tube elongation assay and calculated using liner regression models.

z Mean $\mathrm{EC}_{50} \pm \mathrm{SE}$. 
and sensitive to pyrimethanil and to TBZ as their parental isolates, although the two fludioxonil-resistant mutants derived from the TBZ-S wild-type isolate (W1) became more sensitive to thiabendazole (MIC $\leq 2.5 \mu \mathrm{g} / \mathrm{ml}$ ) than W1 (MIC $=5 \mu \mathrm{g} / \mathrm{ml}$ ) (data not shown). The resistance factors (RF) of the four pyrimethanilresistant mutants to pyrimethanil were $>73$. All four pyrimethanilresistant mutants showed a low level of resistance to fludioxonil,

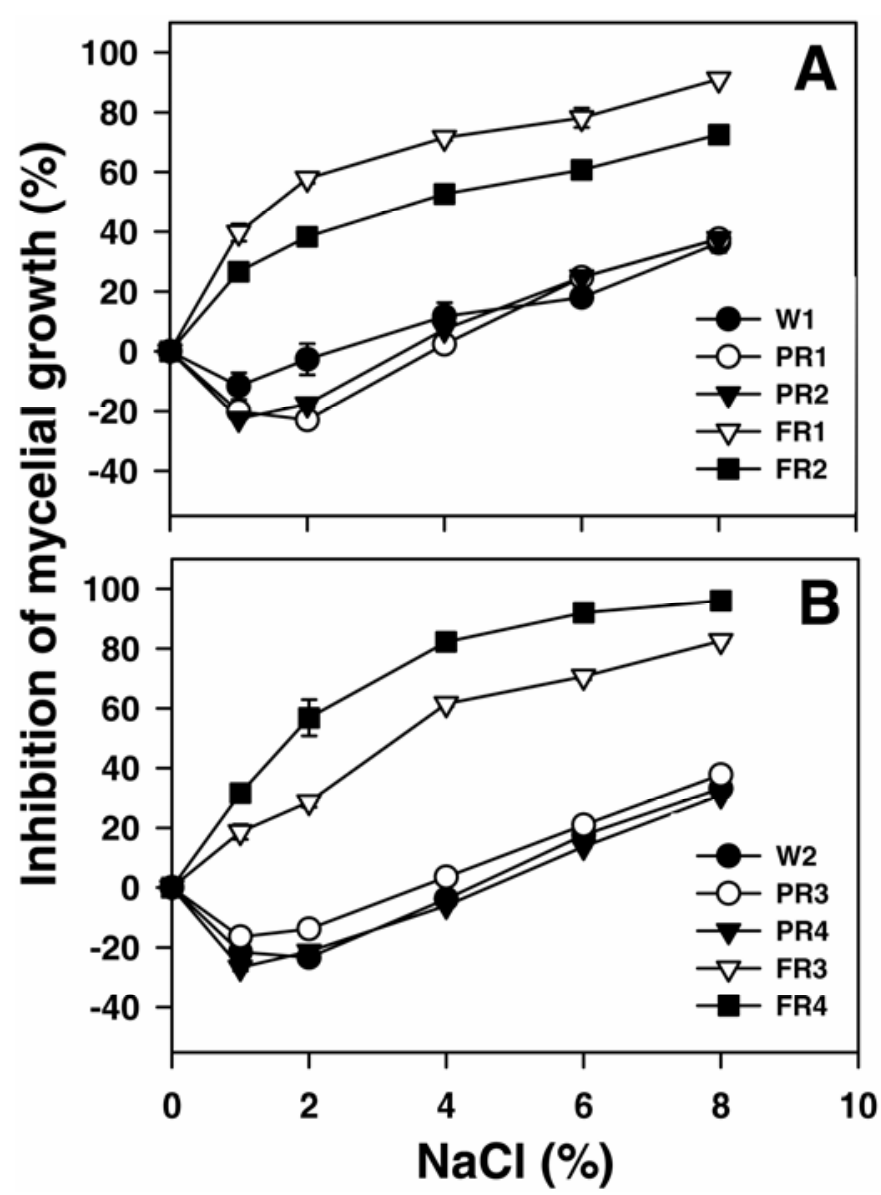

Fig. 1. Inhibition of mycelial growth of Penicillium expansum on potato dextrose agar amended with different $\mathrm{NaCl}$ concentrations. A, Parental wildtype isolate W1 (TBZ-S) and the mutants derived from W1; B, parental wildtype isolate W2 (TBZ-R) and the mutants derived from W2. FR1 to FR4 are fludioxonil-resistant mutants. PR1 to PR4 are pyrimethanil-resistant mutants. Bars represent standard errors. with a resistance factor $>15$. The two pyrimethanil-resistant mutants derived from TBZ-S became resistant to TBZ at $5 \mu \mathrm{g} / \mathrm{ml}$, with a resistance factor $>2$.

Saprophytic fitness of fludioxonil- and pyrimethanil-resistant mutants of $P$. expansum. All four fludioxonil highlyresistant mutants (FR1 to FR4) were sensitive to osmotic pressure and grew slower on PDA amended with $\mathrm{NaCl}$ than their parental isolates (W1 and W2) and pyrimethanil-resistant mutants (Fig. 1). The mycelial growth of fludioxonil highly-resistant mutants was inhibited by more than $50 \%$ on PDA amended with $4 \% \mathrm{NaCl}$. All four pyrimethanil-resistant mutants had the similar levels of sensitivity to $\mathrm{NaCl}$ as the parental isolates. The four pyrimethanilresistant mutants and the parental isolates grew faster on PDA amended with low concentrations of $\mathrm{NaCl}(1$ and $2 \%)$ than on the non- $\mathrm{NaCl}$ control.

All four fludioxonil highly-resistant mutants grew significantly slower on PDA at $20^{\circ} \mathrm{C}$ compared with pyrimethanil-resistant mutants and the wild-type parental isolates, but the differences in mycelial growth at $0^{\circ} \mathrm{C}$ were not consistent with those at $20^{\circ} \mathrm{C}$ (Table 2). Pyrimethanil-resistant mutants PR1 and PR2 grew slower than the parental isolate W1. PR3 grew faster at $20^{\circ} \mathrm{C}$ but slower at $0^{\circ} \mathrm{C}$ than its parental isolate W2. PR4 did not differ significantly in mycelial growth compared with that of W2. There were no significant differences in sporulation among the mutants and wild-type isolates except that FR1 produced fewer spores at $20^{\circ} \mathrm{C}$ and FR4 mutant produced fewer spores on PDA at both 20 and $0^{\circ} \mathrm{C}$ compared with pyrimethanil-resistant mutants and the wild-type parental isolates (Table 2). No significant difference in the conidial germination rate was observed among the mutants and wild-type isolates. No consistent trends in the difference in germ-tube elongation was observed or the difference was marginal (Table 2).

Pathogenic fitness of fungicide-resistant mutants. All fungicide-resistant mutants were pathogenic on apple fruit (Table 3 ). No decay developed on the fruit in the noninoculated control. At $20^{\circ} \mathrm{C}$, nearly all inoculated fruit developed blue mold 10 days after inoculation. At $0^{\circ} \mathrm{C}, 8$ to $88 \%$ of the fruit inoculated with fludioxonil highly-resistant mutants developed blue mold, whereas all fruit inoculated with pyrimethanil-resistant mutants developed blue mold after 12 weeks at $0^{\circ} \mathrm{C}$.

Virulence indices of fludioxonil highly-resistant mutants (FR1 to FR4) were significantly $(P<0.05)$ less than one, indicating these mutants were less virulent than their parental wild-type isolates. It also appeared that fludioxonil highly-resistant mutants were less pathogenic and virulent at $0^{\circ} \mathrm{C}$ than at $20^{\circ} \mathrm{C}$. Virulence indices of pyrimethanil-resistant mutants ranged from 0.8 to 1 . Except for PR1 at $0^{\circ} \mathrm{C}$ and $\mathrm{PR} 2$ at both 0 and $20^{\circ} \mathrm{C}$, pyrimethanil-

TABLE 2. Growth characteristics of fludioxonil- and pyrimethanil-resistant mutants of Penicillium expansum and their parental wild-type isolates on potato dextrose agar

\begin{tabular}{|c|c|c|c|c|c|c|c|}
\hline \multirow[b]{2}{*}{ Parental wild-type isolate } & \multirow[b]{2}{*}{ Mutant } & \multicolumn{2}{|c|}{ Radial growth ${ }^{\mathrm{v}}$} & \multicolumn{2}{|c|}{$\log _{10}$ unit of sporulation ${ }^{w}$} & \multirow[b]{2}{*}{ Conidia germination $(\%)^{\mathrm{x}}$} & \multirow[b]{2}{*}{ Germ-tube elongation ${ }^{y}$} \\
\hline & & $20^{\circ} \mathrm{C}$ & $0^{\circ} \mathrm{C}$ & $20^{\circ} \mathrm{C}$ & $0^{\circ} \mathrm{C}$ & & \\
\hline \multirow[t]{5}{*}{ W1 } & & $44.8 \mathrm{a}^{\mathrm{z}}$ & $26.3 \mathrm{~b}$ & $8.2 \mathrm{a}$ & $7.6 \mathrm{a}$ & $99.6 \mathrm{a}$ & $21.7 \mathrm{ab}$ \\
\hline & FR1 & $33.3 \mathrm{e}$ & $16.9 \mathrm{~d}$ & $8.1 \mathrm{~b}$ & $7.3 \mathrm{a}$ & $99.9 \mathrm{a}$ & $22.1 \mathrm{ab}$ \\
\hline & FR2 & $39.4 \mathrm{c}$ & $30.1 \mathrm{a}$ & $8.2 \mathrm{a}$ & $7.6 \mathrm{a}$ & $100.0 \mathrm{a}$ & $28.8 \mathrm{a}$ \\
\hline & PR1 & $43.5 \mathrm{~b}$ & $19.3 \mathrm{c}$ & $8.2 \mathrm{a}$ & $7.5 \mathrm{a}$ & $100.0 \mathrm{a}$ & $27.1 \mathrm{a}$ \\
\hline & PR2 & $36.6 \mathrm{~d}$ & $19.8 \mathrm{c}$ & $8.2 \mathrm{a}$ & $7.7 \mathrm{a}$ & $100.0 \mathrm{a}$ & $18.0 \mathrm{~b}$ \\
\hline \multirow[t]{5}{*}{ W2 } & & $46.0 \mathrm{~b}$ & $17.9 \mathrm{a}$ & $8.1 \mathrm{a}$ & $7.6 \mathrm{a}$ & $99.9 \mathrm{a}$ & $17.6 \mathrm{ab}$ \\
\hline & FR3 & $29.4 \mathrm{~d}$ & $14.8 \mathrm{~b}$ & $7.9 \mathrm{ab}$ & $7.6 \mathrm{a}$ & $100.0 \mathrm{a}$ & $14.0 \mathrm{~b}$ \\
\hline & FR4 & $33.6 \mathrm{c}$ & $16.9 \mathrm{a}$ & $7.8 \mathrm{~b}$ & $7.3 \mathrm{~b}$ & $99.6 \mathrm{a}$ & $15.8 \mathrm{ab}$ \\
\hline & PR3 & $46.8 \mathrm{a}$ & $14.9 \mathrm{~b}$ & $8.0 \mathrm{a}$ & $7.6 \mathrm{a}$ & $99.6 \mathrm{a}$ & $19.8 \mathrm{ab}$ \\
\hline & PR4 & $45.9 \mathrm{~b}$ & $17.0 \mathrm{a}$ & $8.1 \mathrm{a}$ & $7.6 \mathrm{a}$ & $100.0 \mathrm{a}$ & $21.6 \mathrm{a}$ \\
\hline
\end{tabular}

${ }^{v}$ Mean colony diameter $(\mathrm{mm})$ measured after 7 days of incubation at $20^{\circ} \mathrm{C}$ and 10 weeks at $0^{\circ} \mathrm{C}$.

${ }^{\text {w }}$ Conidia were counted after incubation at $20^{\circ} \mathrm{C}$ for 7 days and $0^{\circ} \mathrm{C}$ for 10 weeks. The data were logarithm-transformed before analysis.

x Percentage of germinated conidia after $24 \mathrm{~h}$ incubation. The data were arcsine-transformed before analysis.

${ }^{y}$ Mean length $(\mu \mathrm{m})$ of germ tube after $24 \mathrm{~h}$ incubation.

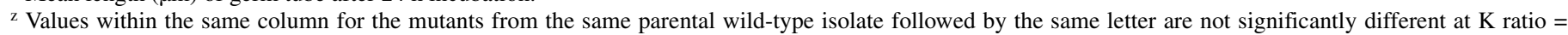
$100(P=0.05)$ according to the Waller-Duncan K-ratio $t$ test. 
resistant mutants were as virulent as their parental isolates (Table 3).

Fludioxonil highly-resistant mutants produced significantly fewer spores on apple fruit than pyrimethanil-resistant mutants and the wild-type parental isolates at both 20 and $0^{\circ} \mathrm{C}$, regardless of whether the total number of conidia or the number of conidia produced per unit of lesion area was considered (Table 3). FR4 did not produce a detectable number of spores on apple fruit. There was no significant difference in sporulation on apple fruit between pyrimethanil-resistant mutants and the parental isolates.

Stability of fungicide-resistant phenotypes. After having been subcultured on PDA following mycelial propagation for 20 successive generations or successive inoculation with conidia as inoculum on apple fruit for four generations, fungicide-resistant mutants had the same levels of resistance to either fludioxonil (data not shown) or pyrimethanil (Table 4). The pyrimethanilresistant mutants of the twentieth generation on PDA and the fourth generation on apple fruit also retained the same levels of resistance to fludioxonil and thiabendazole as their original generations (Table 4). There was no significant difference in virulence index on Red Delicious apples among four generations of each mutant (data not shown).

Efficacy of postharvest fungicides for control of blue mold incited by fungicide-resistant mutants. Pyrimethanil was effective in controlling blue mold caused by fludioxonil-resistant mutants at both $0^{\circ} \mathrm{C}$ and room temperature (Table 5). Fludioxonil was not effective in controlling fludioxonil highly-resistant mutants. Thiabendazole was effective against the fludioxonilresistant mutant FR2 derived from W1 (TBZ-S), but not FR3 derived from W2 (TBZ-R).

Pyrimethanil reduced decay incidence on fruit inoculated with pyrimethanil-resistant mutants by 17 to $27 \%$ and 53 to $59 \%$ at room temperature and $0^{\circ} \mathrm{C}$, respectively (Table 5). The effectiveness of fludioxonil in controlling pyrimethanil-resistant mutants was temperature dependent. At room temperature, fludioxonil was not effective against pyrimethanil-resistant mutants which exhibited a low level of resistance to fludioxonil, whereas at $0^{\circ} \mathrm{C}$ decay caused by pyrimethanil-resistant mutants was considerably reduced by fludioxonil during the 12-week storage. Pyrimethanilresistant mutants (PR1 and PR2) that were derived from TBZ-S showed a low level of resistance to TBZ. At room temperature, TBZ did not provide effective control of blue mold incited by PR1 and PR2. At $0^{\circ} \mathrm{C}$, however, TBZ reduced blue mold incited by PR2 to $6.7 \%$ in comparison with $97.5 \%$ blue mold in the nontreated control (Table 5).

\section{DISCUSSION}

The goal of our study was to assess the potential risk in the development of resistance, including multi-drug resistance, to fludioxonil and pyrimethanil in $P$. expansum populations from apple. Of the six fungicide-resistance phenotypes detected among the fungicide-resistant mutants and their wild-type parental isolates, the four pyrimethanil-resistant mutants of $P$. expansum we examined in this study had multi-drug resistance. Multi-drug resistance to chemically unrelated fungicides has also been reported in Botrytis cinerea (23). Three anilinopyrimidine-resistant phenotypes (Ani R1, Ani R2, and Ani R3) were identified in field populations of $B$. cinerea in French vineyards $(23,24)$. Phenotype Ani R1 is moderately to highly resistant to anilinopyrimidines with a resistance factor ranging from 15 to 250 , and retains a similar level of sensitivity to phenylpyrroles and other classes of fungicides as the wild type strains (24). Phenotype Ani R2 has a low to moderate level of resistance to anilinopyrimidines (resistance factor 5 to 15) and exhibits a low level of resistance to phenylpyrroles and dicarboximides. Phenotype Ani R3 has a low level of resistance to anilinopyrimidines (resistance factor 3 to 7) and dicarboximides, but remains sensitive to phenylpyrroles. Ani R2 and Ani R3 are multi-drug resistance phenotypes and resistance also extends to some other classes of fungicides $(6,23)$. In our study, in terms of resistance to fludioxonil, pyrimethanilresistant phenotypes are similar to the resistant phenotype Ani R2 of $B$. cinerea $(6,23)$. However, in our study the TBZ resistance in the phenotype $\mathrm{TBZ}^{\mathrm{LR}} \mathrm{Flu}^{\mathrm{LR}} \mathrm{Pyr}^{\mathrm{R}}$ appears to be pyrimethanilmediated resistance, because this phenotype was originally derived from a TBZ-S wild-type isolate. Our findings indicate

TABLE 3. Pathogenic fitness parameters of fludioxonil- and pyrimethanil-resistant mutants of Penicillium expansum and their parental isolates on apple fruit

\begin{tabular}{|c|c|c|c|c|c|c|c|c|c|}
\hline \multirow{2}{*}{$\begin{array}{l}\text { Parental wild- } \\
\text { type isolate }\end{array}$} & \multirow[b]{2}{*}{ Mutant } & \multicolumn{2}{|c|}{ Incidence $(\%)$} & \multicolumn{2}{|c|}{ Virulence index ${ }^{y}$} & \multicolumn{2}{|c|}{$\begin{array}{l}\log _{10} \text { unit of conidia } \\
\text { harvested from fruit }\end{array}$} & \multicolumn{2}{|c|}{$\begin{array}{c}\log _{10} \text { unit of conidia } \\
\text { per } \mathrm{cm}^{2} \text { lesion size }\end{array}$} \\
\hline & & $20^{\circ} \mathrm{C}$ & $0^{\circ} \mathrm{C}$ & $20^{\circ} \mathrm{C}$ & $0^{\circ} \mathrm{C}$ & $20^{\circ} \mathrm{C}$ & $0^{\circ} \mathrm{C}$ & $20^{\circ} \mathrm{C}$ & $0^{\circ} \mathrm{C}$ \\
\hline \multirow[t]{5}{*}{$\mathrm{W} 1$} & & 100 & $100 \mathrm{a}^{\mathrm{z}}$ & $1 \mathrm{a}$ & $1 \mathrm{a}$ & $7.3 \mathrm{a}$ & $7.4 \mathrm{a}$ & $6.3 \mathrm{a}$ & $6.2 \mathrm{a}$ \\
\hline & FR1 & 100 & $55.0 \mathrm{c}$ & $0.244 \mathrm{~d}$ & $0.159 \mathrm{c}$ & $1.6 \mathrm{c}$ & $2.9 \mathrm{~b}$ & $1.5 \mathrm{c}$ & $2.4 \mathrm{~b}$ \\
\hline & FR2 & 100 & $85.0 \mathrm{~b}$ & $0.583 \mathrm{c}$ & $0.208 \mathrm{c}$ & $3.9 \mathrm{~b}$ & $2.9 \mathrm{~b}$ & $3.5 \mathrm{~b}$ & $2.5 \mathrm{~b}$ \\
\hline & PR1 & 100 & $100 \mathrm{a}$ & $0.941 \mathrm{a}$ & $0.882 \mathrm{~b}$ & $7.8 \mathrm{a}$ & $7.6 \mathrm{a}$ & $6.8 \mathrm{a}$ & $6.4 \mathrm{a}$ \\
\hline & PR2 & 100 & $100 \mathrm{a}$ & $0.797 \mathrm{~b}$ & $0.878 \mathrm{~b}$ & $6.9 \mathrm{a}$ & $6.8 \mathrm{a}$ & $6.1 \mathrm{a}$ & $5.7 \mathrm{a}$ \\
\hline \multirow[t]{5}{*}{ W2 } & & 100 & $100 \mathrm{a}$ & $1 \mathrm{a}$ & $1 \mathrm{a}$ & $6.9 \mathrm{a}$ & $6.2 \mathrm{a}$ & $6.1 \mathrm{a}$ & $5.2 \mathrm{a}$ \\
\hline & FR3 & 100 & $87.5 \mathrm{~b}$ & $0.481 \mathrm{~b}$ & $0.248 \mathrm{~b}$ & $1.6 \mathrm{~b}$ & $0.6 \mathrm{~b}$ & $1.5 \mathrm{~b}$ & $0.6 \mathrm{~b}$ \\
\hline & FR4 & 94.4 & $7.5 \mathrm{c}$ & $0.214 \mathrm{c}$ & $0.061 \mathrm{c}$ & $0 \mathrm{c}$ & $0 \mathrm{~b}$ & $0 \mathrm{c}$ & $0 \mathrm{~b}$ \\
\hline & PR3 & 100 & $100 \mathrm{a}$ & $0.994 \mathrm{a}$ & $0.960 \mathrm{a}$ & $7.1 \mathrm{a}$ & $6.7 \mathrm{a}$ & $6.2 \mathrm{a}$ & $5.7 \mathrm{a}$ \\
\hline & PR4 & 100 & $100 \mathrm{a}$ & $1.032 \mathrm{a}$ & $0.963 \mathrm{a}$ & $7.1 \mathrm{a}$ & $6.3 \mathrm{a}$ & $6.2 \mathrm{a}$ & $5.2 \mathrm{a}$ \\
\hline
\end{tabular}

y Virulence index = the lesion size of a mutant on decayed apple divided by the lesion size of the parental wild-type isolate.

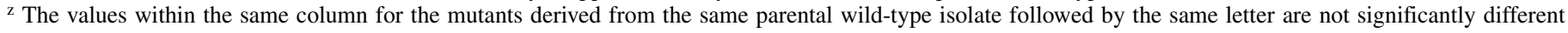
according to the Waller-Duncan K-ratio $t$ test at $\mathrm{K}$ ratio $=100(P=0.05)$.

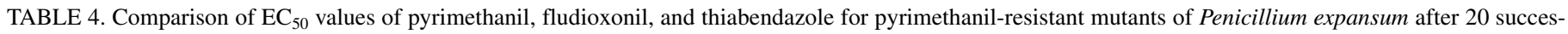
sive generations on potato dextrose agar (PDA) and four successive generations on apple fruit

\begin{tabular}{|c|c|c|c|c|c|c|c|c|c|c|c|c|}
\hline \multirow[b]{2}{*}{ Origin } & \multicolumn{4}{|c|}{ Pyrimethanil $^{\mathrm{x}}$} & \multicolumn{4}{|c|}{ Fludioxonily $^{\mathrm{y}}$} & \multicolumn{4}{|c|}{ Thiabendazole } \\
\hline & PR1 & PR2 & PR3 & PR4 & PR1 & PR2 & PR3 & PR4 & PR1 & PR2 & PR3 & PR4 \\
\hline Original & 13.997 & 15.133 & 13.638 & 13.554 & 0.421 & 0.657 & 0.321 & 0.365 & 1.602 & 1.406 & $>10$ & $>10$ \\
\hline 20 th on PDA & 13.782 & 17.354 & 15.818 & 15.343 & 0.403 & 0.639 & 0.324 & 0.374 & 1.399 & 1.347 & $>10$ & $>10$ \\
\hline 4th on apple & 14.880 & 18.747 & 14.012 & 15.881 & $0.330 * \mathrm{z}$ & 0.644 & $0.298 *$ & 0.366 & 1.565 & 1.272 & $>10$ & $>10$ \\
\hline
\end{tabular}

${ }^{x}$ The $\mathrm{EC}_{50}$ values of pyrimethanil were determined by the germ-tube elongation assay and calculated using liner regression models.

y $\mathrm{The}_{50} \mathrm{EC}_{50}$ values of fludioxonil and thiabendazole were determined by the mycelial growth assays and calculated using liner regression models.

z “*” indicates that the $\mathrm{EC}_{50}$ value was significantly different from that of original generation according to a $t$ test at $P=0.05$. 
that once an isolate of $P$. expansum becomes resistant to pyrimethanil, it could also extend resistance to fludioxonil and possess a low level of resistance to TBZ. It is unknown whether pyrimethanil-mediated resistance to TBZ also occurs in $B$. cinerea. In the reports of Chapeland et al. (6) and Leroux et al. $(23,24)$, sensitivities of Ani R1, Ani R2, and Ani R3 in B. cinerea to TBZ were not tested. To our knowledge, the present study is the first report of pyrimethanil-mediated resistance to TBZ in a fungal pathogen.

Resistance to TBZ in TBZ-resistant mutants of $P$. expansum generated in the laboratory by UV irradiation was associated with point mutations at codons 167, 198, and 200 of $\beta$-tubulin gene (2). A point mutation at codon 198 of $\beta$-tubulin gene has also been observed in highly benzimidazole-resistant isolates of $P$. expansum from natural populations $(2,20,39)$. However, A mutation at codon 198 was not detected in the isolates of $P$. expansum which had a low level of resistance to benomyl; those isolates were able to grow on the medium amended with benomyl at $0.5 \mu \mathrm{g} / \mathrm{ml}$ but not at $5 \mu \mathrm{g} / \mathrm{ml}(20)$. Ma et al. $(29,30)$ also reported a point mutation at codon 6 and codon 240 of the $\beta$ tubulin gene resulting in a level of resistance to benomyl in Monilinia fructicola and M. laxa, respectively. In our study, the pyrimethanil-resistant mutants derived from W1 (TBZ-S) exhibited a low level of resistance to TBZ (active growth on media amended with $5 \mu \mathrm{g} / \mathrm{ml}$ but not with $10 \mu \mathrm{g} / \mathrm{ml}$ ). It is not known whether pyrimethanil-mediated resistance to TBZ also is related to any point mutation of $\beta$-tubulin gene of these mutants. Various ATP-binding cassette and major facilitator superfamily transporters have been reported to be involved in multi-drug resistance development in B. cinerea (41). Future research is needed to understand mechanisms of multi-drug resistance in P. expansum.

In our study, fludioxonil-resistant mutants of $P$. expansum with phenotypes $\mathrm{TBZ}^{\mathrm{S}} \mathrm{Flu}^{\mathrm{HR}} \mathrm{Pyr}^{\mathrm{S}}$ and $\mathrm{TBZ}^{\mathrm{HR}} \mathrm{Flu}^{\mathrm{HR}} \mathrm{Pyr}^{\mathrm{S}}$ were sensitive to osmotic stress. The four pyrimethanil-resistant mutants exhibited a low level of resistance to fludioxonil but were not sensitive to osmotic stress. Previous reports indicated that laboratory fludioxonil-resistant mutants of $B$. cinerea were sensitive to osmotic stress $(16,44,45)$. Similar findings have also been reported on laboratory induced iprodione-resistant mutants of Botryosphaeria dothidea (27) and Alternaria alternata (28), and field iprodione-resistant isolates of $P$. expansum, B. cinerea, and Aspergillus nidulans (3). However, there was no correlation between multiple phenylpyrrole-dicarboximide resistance and osmotic stress regulation in $P$. digitatum from lemon (18). Thus, responses of fludioxonil resistance to osmotic stress regulation may vary by fungal pathogens and phenotypes of fungicide resistant strains. In contrast, in our study pyrimethanil-resistant mutants of $P$. expansum responded to osmotic stress similarly as the wild-type parental isolates and were not sensitive to osmotic stress on PDA amended with 4 to $8 \% \mathrm{NaCl}$. It was considered that osmotic sensitivity may be related to the change in cell wall composition, thereby the fitness of the resistant isolates may be decreased in the field $(3,27)$. The results suggest that fludioxonilresistant strains may not fit well in the environment compared with pyrimethanil-resistant mutants and their wild-type parental isolates.

Pathogenic fitness parameters are important factors in evaluating the potential build-up of fungicide-resistant population of a fungal pathogen (5). Previous reports indicated that pathogenicity or virulence of fludioxonil-resistant isolates or mutants vary by pathogens or phenotypes of the pathogen. For example, osmoticsensitive phenylpyrrole-resistant mutants of $B$. cinerea are as virulent as the wild-type parental isolate (44) or lose their pathogenicity on apple fruit (16). Kanetis et al. (18) found that fludioxonil-resistant isolates of $P$. digitatum from citrus with $\mathrm{EC}_{50}$ values between 0.21 and $0.45 \mu \mathrm{g} / \mathrm{ml}$ were less pathogenic (low

TABLE 5. Efficacy of three apple-postharvest fungicides for the control of blue mold incited by fludioxonil- and pyrimethanil-resistant mutants and their parental wild-type isolates of Penicillium expansum in Red Delicious apple fruit

\begin{tabular}{|c|c|c|c|c|c|c|}
\hline \multirow[b]{2}{*}{ Isolate } & \multirow[b]{2}{*}{ Treatment ${ }^{\mathrm{y}}$} & \multicolumn{2}{|c|}{ Room temperature (RT) for 10 days } & \multicolumn{2}{|c|}{ Cold storage $\left(0^{\circ} \mathrm{C}\right)$ for 12 weeks } & \multirow{2}{*}{$\begin{array}{c}\text { Cold storage }\left(0^{\circ} \mathrm{C}\right) \text { for } 12 \text { weeks } \\
\text { and RT for another week } \\
\text { Incidence }(\%)\end{array}$} \\
\hline & & Incidence $(\%)$ & Lesion size $(\mathrm{mm})$ & Incidence (\%) & Lesion size $(\mathrm{mm})$ & \\
\hline \multirow[t]{3}{*}{ W1 } & Nontreated & $100 a^{z}$ & $41.8 \mathrm{a}$ & $95.8 \mathrm{a}$ & $43.8 \mathrm{a}$ & $100 \mathrm{a}$ \\
\hline & Fludioxonil & $0 \mathrm{~b}$ & $0 \mathrm{~b}$ & $0 \mathrm{~b}$ & $0 \mathrm{~b}$ & $3.3 \mathrm{~b}$ \\
\hline & Pyrimethanil & $0 \mathrm{~b}$ & $0 \mathrm{~b}$ & $0 \mathrm{~b}$ & $0 \mathrm{~b}$ & $0.8 \mathrm{bc}$ \\
\hline FR2 & Nontreated & $100 \mathrm{a}$ & $19.1 \mathrm{~b}$ & $81.7 \mathrm{a}$ & $17.2 \mathrm{a}$ & $100 \mathrm{a}$ \\
\hline \multirow[t]{4}{*}{ PR1 } & Nontreated & $100 \mathrm{a}$ & $36.7 \mathrm{a}$ & & & \\
\hline & Thiabendazole & $57.3 \mathrm{~b}$ & $15.8 \mathrm{~d}$ & & & \\
\hline & Fludioxonil & $100 \mathrm{a}$ & $27.6 \mathrm{~b}$ & & & \\
\hline & Pyrimethanil & $97.5 \mathrm{a}$ & $19.7 \mathrm{c}$ & & & \\
\hline \multirow[t]{2}{*}{ PR2 } & Nontreated & $100 \mathrm{a}$ & $23.8 \mathrm{a}$ & $97.5 \mathrm{a}$ & $30.6 \mathrm{a}$ & $100 \mathrm{a}$ \\
\hline & Thiabendazole & $74.2 \mathrm{~b}$ & $15.4 \mathrm{bc}$ & $6.7 \mathrm{~d}$ & $4.6 \mathrm{c}$ & $10 \mathrm{c}$ \\
\hline W2 & Pyrimethanil & $0 \mathrm{~b}$ & $0 \mathrm{~b}$ & $0 \mathrm{c}$ & $0 \mathrm{c}$ & $0 \mathrm{~b}$ \\
\hline \multirow[t]{4}{*}{ FR3 } & Nontreated & $99.2 \mathrm{a}$ & $12.4 \mathrm{~b}$ & $49.2 \mathrm{~b}$ & $12.6 \mathrm{ab}$ & $92.5 \mathrm{~b}$ \\
\hline & Thiabendazole & $100 \mathrm{a}$ & $12.7 \mathrm{~b}$ & $74.8 \mathrm{a}$ & $14.2 \mathrm{a}$ & $98.3 \mathrm{a}$ \\
\hline & Fludioxonil & $100 \mathrm{a}$ & $17.4 \mathrm{a}$ & $62.5 \mathrm{ab}$ & $10.1 \mathrm{~b}$ & $99.2 \mathrm{a}$ \\
\hline & Pyrimethanil & $0 \mathrm{~b}$ & $0 \mathrm{c}$ & $0 \mathrm{c}$ & $0 \mathrm{c}$ & $0 \mathrm{c}$ \\
\hline \multirow{4}{*}{ PR4 } & Nontreated & $100 \mathrm{a}$ & $35.2 \mathrm{a}$ & $93.3 \mathrm{a}$ & $26.1 \mathrm{a}$ & $100 \mathrm{a}$ \\
\hline & Thiabendazole & $99.2 \mathrm{a}$ & $34.4 \mathrm{a}$ & $97.5 \mathrm{a}$ & $28.1 \mathrm{a}$ & $100 \mathrm{a}$ \\
\hline & Fludioxonil & $99.2 \mathrm{a}$ & $24.8 \mathrm{~b}$ & $10.0 \mathrm{c}$ & $9.1 \mathrm{c}$ & $60.0 \mathrm{c}$ \\
\hline & Pyrimethanil & $83.3 \mathrm{~b}$ & $15.8 \mathrm{c}$ & $37.5 \mathrm{~b}$ & $16.0 \mathrm{~b}$ & $84.2 \mathrm{~b}$ \\
\hline
\end{tabular}

${ }^{\mathrm{y}}$ Nontreated, thiabendazole, fludioxonil, and pyrimethanil were applied as sterile deionized water, Mertect 340F at $1.25 \mathrm{ml} /$ liter, Scholar $50 \mathrm{WP}$ at $0.6 \mathrm{~g} /$ liter, and Penbotec $400 \mathrm{SC}$ at $1.25 \mathrm{ml} /$ liter, respectively.

${ }^{\mathrm{z}}$ The data within the same column for each isolate followed by the same letter are not significantly different according to the Waller-Duncan K-ratio $t$ test at $\mathrm{K}$ ratio $=100(P=0.05)$. 
disease incidence) but highly virulent (large decay lesion) on citrus fruit, and the isolates with $\mathrm{EC}_{50}$ values $>0.79 \mu \mathrm{g} / \mathrm{ml}$ were highly pathogenic but less virulent. In our study, pathogenicity of fludioxonil-resistant mutants with phenotypes $\mathrm{TBZ}^{\mathrm{S}} \mathrm{Flu}^{\mathrm{HR}} \mathrm{Pyr}^{\mathrm{S}}$ and $\mathrm{TBZ}^{\mathrm{HR}} \mathrm{Flu}^{\mathrm{HR}} \mathrm{Pyr}^{\mathrm{S}}$ was temperature dependent. These four fludioxonil highly-resistant mutants were as pathogenic as the wildtype parental isolates at $20^{\circ} \mathrm{C}$ but less pathogenic at $0^{\circ} \mathrm{C}$, and they were all less virulent and produced fewer spores on apple fruit compared with the parental wild-type isolates regardless of temperature. Similar results were found in osmotic-sensitive isolates of $B$. cinerea resistant to phenylpyrrole (45). However, all pyrimethanil-resistant mutants in $P$. expansum were as pathogenic as the wild-type parental isolates and exhibited equivalent or slightly reduced virulence on apple fruit compared with the wild-type parental isolates.

Taken together, our results indicate that a fitness cost was associated with fludioxonil highly resistant phenotypes of $P$. expansum in both saprophytic and pathogenic phases of the pathogen but not pyrimethanil-resistant phenotypes. Furthermore, pyrimethanil likely possesses a higher risk than fludioxonil in the development of resistance in P. expansum.

Resistance stability also is an important factor affecting the build-up of a fungicide resistant population in a fungal pathogen (5). It appears that resistance stability of fungicide-resistant mutants or field isolates is dependent upon the pathogen and fungicide involved. For example, fludioxonil-resistant mutants of $B$. cinerea that are sensitive to osmotic stress exhibit a reduced resistance when grown on a fungicide-free medium (45). Iprodione-resistance of $B$. dothidea significantly declined on pistachio leaves in the absence of fungicide (27). Whereas, $B$. cinerea populations resistant to thiophanate-methyl and vinclozolin remain the same level of resistance after being sub-cultured for 20 generations on PDA or 15 generations on geranium seedlings (43). Similarly, persistence of thiabendazole-resistance of $P$. expansum on apple fruit (34) was reported. In our experiments, the subcultured mutants of $P$. expansum from the twentieth generations on a fungicide-free PDA and fourth generations on apple fruit exhibited the same phenotypes as their parental generations. The results indicate that resistance of $P$. expansum to fludioxonil and pyrimethanil was stable regardless of whether the tests were done in vitro or in vivo.

The results on the efficacy of the three postharvest fungicides for controlling blue mold in apple fruit incited by the fungicideresistant mutants were generally in agreement with that of in vitro sensitivity tests. The efficacy of fludioxonil on control of blue mold incited by pyrimethanil-resistant mutants (PR2 and PR4) was reduced during the 12 -week storage at $0^{\circ} \mathrm{C}$ compared with that at $20^{\circ} \mathrm{C}$, but the incidence of blue mold increased to 60 to $84 \%$ after the fruit were kept for one more week at room temperature. This was likely due to slow growth of the pathogen and stable residues of fludioxonil on the fruit at $0^{\circ} \mathrm{C}$. The efficacy of TBZ against blue mold incited by pyrimethanil-resistant mutant PR2 (derived from TBZ-S wild-type isolate) was reduced at $0^{\circ} \mathrm{C}$ as compared with that at room temperature, but the decay incidence remained at the similar level after the fruit were stored at room temperature for one more week following cold storage. This may suggest that effectiveness of TBZ in controlling multidrug resistant phenotypes exhibiting a low level of resistance to TBZ was temperature dependent. Although pyrimethanil did not provide effective control of blue mold incited by pyrimethanilresistant mutants at room temperature, it reduced blue mold incidence by 53 to $60 \%$ at $0^{\circ} \mathrm{C}$ compared with the nontreated control. The results indicate that if fludioxonil and pyrimethanil are used as a postharvest drench treatment prior to cold storage or as a dip treatment in the packing line, they still have some effects on blue mold caused by triple-resistant isolates of $P$. expansum during cold storage, but after the fruit have been shipped to the market, blue mold incidence will likely increase because fludioxonil and pyrimethanil lose their efficacy at room temperature for control of blue mold incited by the triple-resistant phenotypes of $P$. expansum.

In conclusion, using a mutagenesis approach we found that pyrimethanil-resistant phenotypes of $P$. expansum also extended resistance to fludioxonil, that pyrimethanil-resistant mutants derived from TBZ-S became resistant to TBZ, and that a fitness cost was associated with fludioxonil highly-resistant phenotypes of $P$. expansum in both saprophytic and pathogenic phases of the pathogen but not pyrimethanil-resistant phenotypes. Our results indicate that pyrimethanil possesses a higher risk than fludioxonil in the development of resistance in $P$. expansum, and that triple resistance to TBZ, fludioxonil, and pyrimehtanil could develop and become a practical problem if the pathogen develops resistance to pyrimethanil in the pathogen populations. However, it also is worthwhile to mention that fungicide-resistance phenotypes of laboratory mutants may or may not become established under commercial conditions, depending on the presence of selection pressure, fitness, and competition. Nonetheless, these findings will be instrumental in the development and implementation of relevant strategies for management of fungicide resistance in $P$. expansum and control of blue mold in apple.

\section{ACKNOWLEDGMENTS}

Plant Pathology New Series 0467, Department of Plant Pathology, College of Agricultural, Human, and Natural Resource Sciences Agricultural Research Center, Project No. WNP0367, Washington State University, Pullman, WA 99164-6430, USA. We thank R. J. Boal for technical assistance. This research was supported in part by the Washington Tree Fruit Research Commission.

\section{LITERATURE CITED}

1. Adaskaveg, J. E., Forster, H., and Sommer, N. F. 2002. Principles of postharvest pathology and management of decays of edible horticultural crops. Pages 163-195 in: Postharvest Technology of Horticultural Crops. 3rd ed. A. A. Kader, ed. University of California Agricultural and Natural Resources Publ. 3311.

2. Baraldi, E., Mari, M., Chierici, E., Pondrelli, M., Bertolini, P., and Pratella, G. C. 2003. Studies on thiabendazole resistance of Penicillium expansum of pears: Pathogenic fitness and genetic characterization. Plant Pathol. 52:362-370.

3. Beever, R. E. 1983. Osmotic sensitivity of fungal variants resistant to dicarboximide fungicides. Trans. Br. Mycol. Soc. 80:327-331.

4. Bertrand, P. F., and Saulie-Carter, J. L. 1978. The occurrence of benomyltolerant strains of Penicillium expansum and Bortytis cinerea in the midColumbia region of Oregon and Washington. Plant Dis. Rep. 62:302-305.

5. Brent, K. J., and Hollomon, D. W. 1998. Pages 1-48 in: Fungicide Resistance: The Assessment of Risk. FRAC Monograph No. 2. Global Crop Protection Federation, Brussels, Belgium.

6. Chapeland, F., Fritz, R., Lanen, C., Gredt, M., and Leroux P. 1999. Inheritance and mechanisms of resistance to anilinopyrimidine fungicides in Bortytis cinerea (Botryotinia fuckeliana). Pestic. Biochem. Phys. 64:85-100

7. Delp, C. J., and Dekker, J. 1985. Fungicide resistance: Definition and use of terms. Bull. OEPP/EPPO Bull. 15:333-335.

8. Eckert, J. W., and Ogawa, J. M. 1988. The chemical control of postharvest diseases: Deciduous fruits, berrie, vegetables and root/tuber crops. Annu. Rev. Phytopathol. 26:433-469.

9. Errampalli, D. 2004. Effect of fludioxonil on germination and growth of Penicillium expansum and decay in apple cvs. Empire and Gala. Crop Prot. 23:811-817.

10. Errampalli, D., Brubacher, N. R., and DeEll, J. R. 2006. Sensitivity of Penicillium expansum to diphenylamine and thiabendazole and postharvest control of blue mold with fludioxonil in 'McIntosh' apples. Postharvest Biol. Technol. 39:101-107.

11. Errampalli, D. and Crnko, N. 2004. Control of blue mold caused by Penicillium expansum on apples 'Empire' with fludioxonil and cyprodinil. Can. J. Plant Pathol. 26:70-75.

12. Faretra, F., and Pollastro, S. 1993. Isolation, characterization and genetic analysis of laboratory mutants of Botryotinia fuckeliana resistant to the phenylpyrrole fungicide CGA 173506. Mycol. Res. 97:620-624.

13. Forster, B., and Staub, T. 1996. Basis for use strategies of anilinopyrimidine and phenylpyrrole fungicides against Botrytis cinerea. Crop Prot. 15:529-537. 
14. Hiber, U. W., and Hiber-Bodmer, M. 1998. Genetic basis and mornitoring of resistance of Botryotinia fuckeliana to anilinopyrimidines. Plant Dis. 82:496-500.

15. Hiber, U. W., and Schüepp, H. 1996. A reliable method for testing the sensitivity of Botryotinia fuckeliana to anilinopyrimidines in vitro. Pestic. Sci. 47:241-247.

16. Hiber, U. W., Schüepp, H., and Schwinn, F. J. 1994. Resistance risk evaluation of fludioxonil, a new phenylpyrrole fungicide. Pages 397-402 in: Fungicide Resistance, Monograph No.60. S. Heaney, D. Slawson, D. W. Hollomon, M. Smith, P. E. Russel, and D. W. Perry, eds. British Crop Protection Council, Farnham, Surrey, UK.

17. Iacomi-Vasilescu, B., Avenot, H., Bataillé-Simoneau, N., Laurent, E., Guénard, M., and Simoneau, P. 2004. In vitro fungicide sensitivity of Alternaria species pathogenic to crucifers and identification of Alternaria brassicicola field isolates highly resistant to both dicarboximides and phenylpyrroles. Crop Prot. 23:481-488.

18. Kanetis, L., Forster, H., and Adaskaveg, J. E. 2006. Fludioxonil-resistant isolates of Penicillium digitatum show diverse fitness and no relationship to osmotic stress regulation. (Abstr.) Phytopathology 96(suppl.):S58.

19. Kinay, P., Mansour, M. F., Gabler, F. M., Margosan, D. A., and Smilanick, J. L. 2007. Characterization of fungicide-resistant isolates of Penicillium digitatum collected in California. Crop Prot. 26:647-656.

20. Koenraadt, H., Somerville, S. C., and Jones, A. L. 1992. Characterization of mutations in the beta-tubulin gene of benomyl-resistant field strains of Venturia inaequalis and other plant pathogenic fungi. Phytopathology 82:1348-1354.

21. Latorre, B. A., Spadaro, I., and Rioja, M. E. 2002. Occurrence of resistance strains of Botrytis cinerea to anilinopyrimidine fungicides in table grapes in Chile. Crop Prot. 21:957-961.

22. Lennox, C. L., Spotts, R. A., and Booyse, M. 2004. Incidence of postharvest decay of 'd'Anjou' pear and control with a thiabendazole drench. Plant Dis. 88:474-478.

23. Leroux, P., Chapeland, F., Desbrosses, D., and Gredt, M. 1999. Patterns of cross-resistance to fungicides in Botryotinia fuckeliana (Botrytis cinerea) isolates from French vineyards. Crop Prot. 18:687-697.

24. Leroux, P., Frita, R., Debiu, D., Albertini, C., Lanen, C., Bach, J., Gredt, M., and Chapeland, F. 2002. Mechanisms of resistance to fungicides in field strains of Botrytis cinerea. Pest Manag. Sci. 58:876-888.

25. Leroux, P., and Gredt, M. 1996. In vitro methods for monitoring pyrimethanil resistance of Botrytis cinerea in grapevine. Bull. OEPP/EPPO Bull. 26:186-188.

26. Li, H. X., and Xiao, C. L. 2008. Baseline sensitivities to fludioxonil and pyrimethanil in Penicillium expansum populations from apple in Washington State. Postharvest Biol. Technol. 47:239-245.

27. Ma, Z., Luo, Y., and Michailides, T. J. 2001. Resistance of Botryosphaeria dothidea from pistachio to iprodione. Plant Dis. 85:183-188.

28. Ma, Z., and Michailides, T. J. 2004. Characterization of iprodioneresistant Alternaria isolates from pistachio in California. Pestic. Biochem. Physiol. 80:75-84.

29. Ma, Z., Yoshimura, M. A., Holtz, B. A., and Michailides, T. J. 2005. Characterization and PCR-based detection of benzimidazole-resistant isolates of Monilinia laxa in California. Pest Manag. Sci. 61:449-457.

30. Ma, Z., Yoshimura, M. A., and Michailides, T. J. 2003. Identification and characterization of benzimidazole resistance in Monilinia fructicola from stone fruit orchards in California. Appl. Environ. Microbiol. 69:71457152.

31. Moyano, C., Gómez, V., and Melgarejo, P. 2004. Resistance to pyrimethanil and other fungicides in Botrytis cinerea populations collected on vegetable crops in Spain. J. Phytopathol. 152:484-490.

32. Myresiotis, C. K., Karaoglanidia, G. S., and Tzavella-Klonari, K. 2007. Resistance of Botrytis cinerea isolates from vegetable crops to anilinopyrimidine, phenylpyrrole, hydroxyanilide, benzimidazole, and dicarboximide fungicides. Plant Dis. 91:407-413.

33. Petsikos-Panayotarou, N., Markellou, E., and Kalamarakis, A. E. 2003. In vitro and in vivo activity of cyprodinil and pyrimethanil on Botrytis cinerea isolates resistant to the other botryticides and selection for resistance to pyrimethanil in a greenhouse population in Greece. Eur. J. Plant Pathol. 109:173-182.

34. Prusky, D., Bazak, M., and Ben-Arie, R. 1985. Development, persistence, survival, and strategies for control of thiabendazole-resistant strains of Penicillium expansum on pome fruits. Phytopathology 75:877-882.

35. Rosenberger, D. A. 1990. Blue mold. Pages 54-55 in: Compendium of Apple and Pear Diseases. A. L. Jones, and H. S. Aldwinkle, eds. American Phytopathological Society, St. Paul, MN.

36. Rosenberger, D. A., and Meyer, F. W. 1979. Benomyl-tolerant Penicillium expansum in apple packinghouses in eastern New York. Plant Dis. Rep. 63:37-40.

37. Rosenberger, D. A., Wicklow, D. T., Korjagin, V. A., and Rondinaro, S. M. 1991. Pathogenicity and benzimidazole resistance in Penicillium species recovered from flotation tanks in apple packinghouses. Plant Dis. 75:712715 .

38. Sanderson, P. G., and Spotts, R. A. 1995. Postharvest decay of winter pear and apple fruit caused by species of Penicillium. Phytopathology 85:103110 .

39. Sholberg, P. L., Bedford, K., and Stokes, S. 2005. Sensitivity of Penicillium spp. and Botrytis cinerea to pyrimethanil and its control of blue and grey mold of stored apples. Crop Prot. 24:127-134.

40. Spotts, R. A., and Cervants, L .A. 1993. Filtration to remove spores of Penicillium expansum from water in pome fruit packinghouses. Tree Fruit Postharvest J. 4:16-18.

41. Vermeulen, T., Schoonbeek, H., Waard, M. A. de. 2001. The ABC transporter BcatrB from Botrytis cinerea is a determinant of the activity of the phenylpyrrole fungicide fludioxonil. Pest Manag. Sci. 57:393-402.

42. Young, D. H., Spiewak, S. L., and Slawecki, R. A. 2001. Laboratory studies to assess the risk of development of resistance to zoxamide. Pest Manag. Sci. 57:1081-1087.

43. Yourman, L. F., Jeffers, S. N., and Dean, R. A. 2001. Phenotype instability in Botrytis cinerea in the absence of benzimidazole and dicarboximide fungicides. Phytopathology 91:307-315.

44. Ziogas, B. N., and Kalamarakis, A. E. 2001. Phenylpyrrole fungicides: Mitotic instability in Aspergilliun nidulans and resistance in Botrytis cinerea. J. Phytopathol. 149:301-308.

45. Ziogas, B. N., Markoglou, A. N., and Spyropoulou, V. 2005. Effect of phenylpyrrole-resistance mutations on ecological fitness of Botrytis cinerea and their genetical basis in Ustilago maydis. Eur. J. Plant Pathol. 113:83-100. 